\title{
Acute Phase Proteins: Journey of Pivotal Marker in Periodontal Disease
}

\author{
Surbhi Khaparde ${ }^{1}$, Vishnudas Bhandari ${ }^{2}$, Gauri Ugale ${ }^{3}$, Rashmi Jawade ${ }^{4}$, \\ Mukesh Ardale ${ }^{5}$, Kailash Mundada ${ }^{6}$. \\ ${ }^{I}$ (Department Of Periodontics, MIDSR Dental College And Hospital, Latur, Maharashtra, India) \\ ${ }^{2}$ (Department Of Periodontics, MIDSR Dental College And Hospital, Latur, Maharashtra, India) \\ ${ }^{3}$ (Department Of Periodontics, MIDSR Dental College And Hospital, Latur, Maharashtra, India) \\ ${ }^{4}$ (Department Of Periodontics, MIDSR Dental College And Hospital, Latur, Maharashtra, India) \\ ${ }_{5}^{5}$ (Department Of Periodontics, MIDSR Dental College And Hospital, Latur, Maharashtra, India) \\ ${ }^{6}$ (Department Of Periodontics, Darshan Dental College And Hospital, Udaipur, Rajasthan, India)
}

\begin{abstract}
Periodontal disease is a chronic and concealed infection. It has become progressively clearer in recent years that periodontal disease can cause remarkable increase as well as decrease in the levels of markers of systemic inflammation. These markers include chiefly plasma proteins such as acute phase proteins. The acute phase proteins are an evolutionarily conserved family of proteins produced mainly in the liver in response to infection and inflammation. Acute phase proteins are generated in the host by a process called as acute phase reaction which is mediated by cytokines like Interleukin-1, 6, 8 and tumor necrosis factor- $\alpha$. The rise in the plasma concentration of acute phase proteins can assist host defense by aiding recognition of invading microbes, mobilization of leukocytes into the circulation, and increasing blood flow to injured or infected sites. This review reiterates on the structure, synthesis, classification, functions of acute phase proteins and their interrelationship with periodontal disease.
\end{abstract}

Keywords: Acute phase proteins, acute phase response, inflammation and periodontitis.

\section{Introduction}

Periodontitis is a polymicrobial infectious disease of multifactorial origin involving supporting structures of the teeth. It triggers an array of events which involves innate \& adaptive immunity as well as inflammatory response in the host.[1] The characteristic of this response is infiltration of the periodontal tissue with multiple inflammatory cells which include polymorphonuclear neutrophils, macrophages, lymphocytes \& plasma cells.[2] Even though periodontitis is localized to periodontal tissue, this disease appears to be sufficient to influence the acute phase response systemically.

One of the most interesting features of the acute-phase is the change in the concentrations of many plasma proteins, known as the acute-phase proteins. An acute-phase protein (APP) has been defined as one whose plasma concentration increases (positive acute-phase proteins) or decreases (negative acute-phase proteins) by at least 25 percent during inflammatory disorders. [3]

The systematic search of literature was carried out to identify relevant studies by using key words like acute phase proteins, acute phase response, inflammation and periodontitis in PUBMED, MEDLINE, COCHRANE and Google databases. Out of 587 searched articles, 47 articles describing acute phase proteins and its relation to periodontitis were used to prepare a concise review. This review will focus on the knowledge acquired on acute phase reactants in particular to role of acute phase proteins in systemic and periodontal disease.

\section{Acute Phase Reaction}

The acute-phase response is critical to the body's ability to successfully respond to injury. It normally lasts only few days; however, if continuously unchecked, the acute phase response may contribute to the development of chronic inflammatory states, tissue damage and disease. (Fig. 1) The acute phase response is typically characterized by fever and changes in vascular permeability, along with profound changes in the biosynthetic profile of various acute phase proteins (APPs).[4] APPs are an evolutionarily conserved family of proteins produced mainly in the liver in response to infection and inflammation.

The rise in the plasma concentration of APPs assist host defense by aiding recognition of invading microbes, mobilization of leukocytes into the circulation, and increasing blood flow to injured or infected sites.[5] 


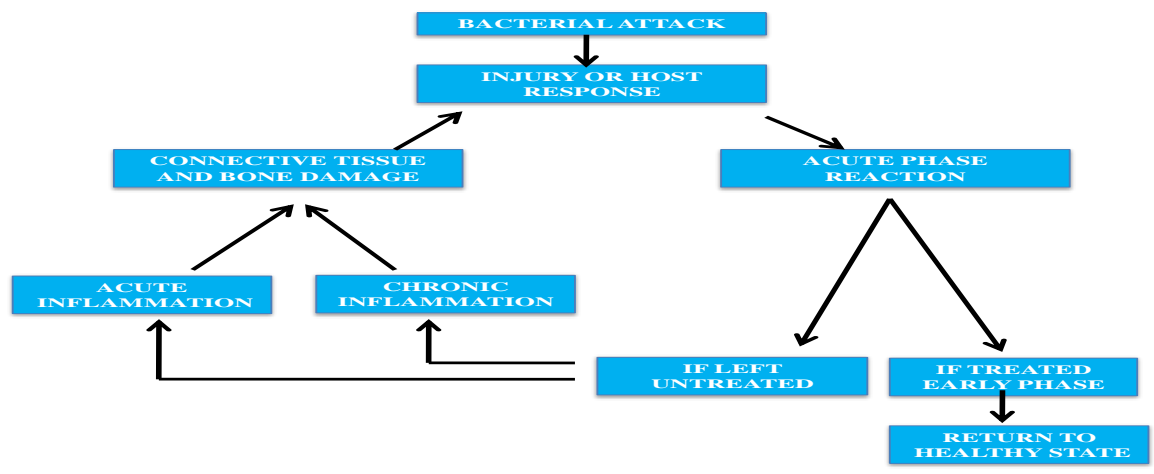

Figure 1: Apparent model of acute-phase response

\section{Synthesis Of Acute Phase Proteins}

The synthesis of these acute-phase proteins has been shown to be regulated by cytokines and to a lesser extent by glucocorticoid hormones. Arbitrarily, cytokines related to the acute phase response can be divided into three groups:

(i) Pro-inflammatory cytokines initiating or enhancing the cascade of events TNF- $\alpha$, IL-1, INF- $\gamma$ and IL-8.

(ii) IL-6- type cytokines (IL-6, leukemia inhibitory factor [LIF], IL- 11, oncostatin M, ciliary neurotrophic factor and cardiotrophin-1), which are held responsible for the main systemic features of acute-phase response in a variety of tissues.

(iii) Anti-inflammatory cytokines down regulating the acute-phase response (IL- 10, IL-4, IL-13 and TGF- $\beta$.[6]

\section{Structure Of Acute Phase Proteins}

Acute-phase proteins (APPs) are serum molecules which are synthesized by many cells categories, especially by hepatocytes. Usually, the structure of APPs and acute-phase responses are similar in all species, having universal character in animal kingdom. Biochemical structure of APPs is distinct, many of them being glycoproteins. Glycosylation are higher in molecules synthesized during the acute-phase responses. Exceptions are C-reactive protein (CRP) and serum amyloid A (SAA), important APPs which are not glycosylate. SAA has a particular structure (apolipoprotein), being characterized by high polymorphism. SAA is synthesized by other cells (non-hepatic types).[7]

\section{Disease Chronicity}

During the lifespan of an organism acute phases occur following hits (stimulus) yielding high concentrations of major APPs, influx of inflammatory cells and higher production of inflammatory cytokines and chemokines to the site all acting in defense of the organism. The process is resolved through a complex mechanism yielding physiological levels of APPs. If, however, there are too many hits, leading to an acute phase which cannot be resolved, this may lead to irreversible chronicity with high, medium or low grade inflammation. (Fig.2) [8]

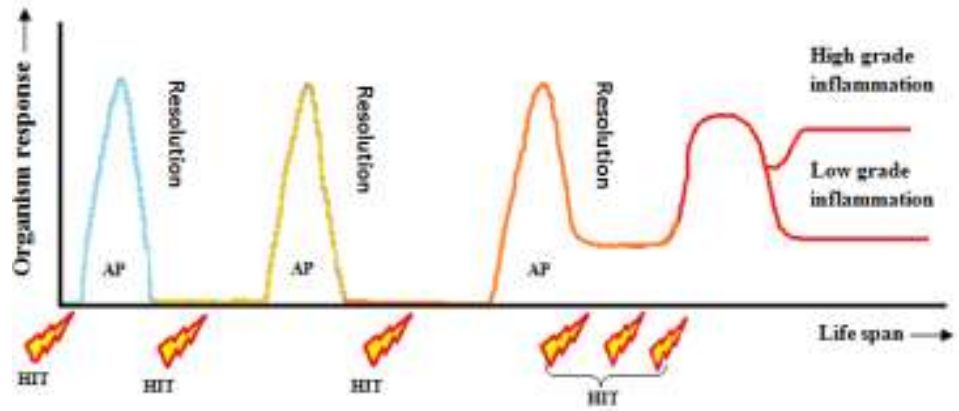

Figure 2: Time span of APP level changes leading to disease chronicity, AP: acute phase, HIT; represents injuries, infections, neoplasia and/or inflammation.

\section{Resolution Of Inflammation And Termination Of Acute Phase Response}

After the injury-elicited initiation of inflammatory reaction followed by fully developed inflammatory response the resolution phase is expected. In reality, however, this scheme is not always observed and at least three different results are possible: (a) acute illness with a fatal outcome; (b) prolonged chronic disease; (c) prompt return to health after a period of reconvalescence.[8] 
VII. Classification Of Acute Phase Proteins[8]

TABLE 1: Classification according to Mackiewicz A (1993)

\begin{tabular}{|c|c|c|}
\hline $\begin{array}{l}\text { APP groups during APR } \\
\text { (Fold increase/decrease) }\end{array}$ & Name of the APP and normal levels & Representative Functions \\
\hline \multirow[t]{2}{*}{$\begin{array}{l}\text { Positive Major APP, >5 } \\
\text { fold increase }\end{array}$} & $\begin{array}{l}\text { Serum amyloid } A \\
\left(<10^{1}\right)\end{array}$ & $\begin{array}{l}\text { Cytokine like chemoattractant, induction of matrix } \\
\text { metalloproteinases, adhesion molecules, lipid } \\
\text { metabolism }\end{array}$ \\
\hline & $\begin{array}{l}\text { C-reactive protein } \\
\left(<5^{1}\right)\end{array}$ & Opsonization. \\
\hline \multirow[t]{11}{*}{$\begin{array}{l}\text { Positive Moderate APP, } \\
\sim 2-5 \text { fold increase }\end{array}$} & $\begin{array}{l}\text { Haptoglobulin } \\
\left(400-1800^{1}\right)\end{array}$ & Binds hemoglobin, limits iron loss. \\
\hline & $\begin{array}{l}\text { lpha 1-Acid glycoprotein } \\
\left(400-1050^{2}\right)\end{array}$ & $\begin{array}{l}\text { Carrier of lipophilic components, steroid carrier, } \\
\text { immunosuppressive for lymphocytes. }\end{array}$ \\
\hline & $\begin{array}{l}\text { Mannose binding lectin } \\
\left(1.4^{3}\right)\end{array}$ & $\begin{array}{l}\text { Pathogen recognition molecule, opsonising } \\
\text { microorganism, initiating the complement cascade. }\end{array}$ \\
\hline & $\begin{array}{l}\square \text { Ipha 1-Antichymotrypsin } \\
\left(300-1600^{1}\right)\end{array}$ & Protease inhibitor. \\
\hline & $\begin{array}{l}\text { Ipha 1-Antitrypsin } \\
\left(2000-4000^{2}\right)\end{array}$ & $\begin{array}{l}\text { Protease inhibitor, induction of cell proliferation, } \\
\text { synthesis of collagen, chemoattractant. }\end{array}$ \\
\hline & $\begin{array}{l}\text { Fibrinogen } \\
\left(1000-4000^{2}\right)\end{array}$ & Clot formation \\
\hline & $\begin{array}{l}\text { Secretory phospholipase A2 } \\
\left(15.1-32.1 \mathrm{U} / \mathrm{ml}^{4}\right)\end{array}$ & $\begin{array}{l}\text { Increase expression of inflammatory cytokines, } \\
\text { associates with lipoprotein }\end{array}$ \\
\hline & $\begin{array}{l}\text { Fibronectin } \\
\left(234^{5}\right)\end{array}$ & $\begin{array}{l}\text { Binds to extracellular matrix and integrins, important } \\
\text { in cell adhesion, migration, wound healing, forms } \\
\text { immunecomplex with C1q, fibrin clot formation }\end{array}$ \\
\hline & $\begin{array}{l}\text { von Willebrand factor } \\
\left(107 \mathrm{U} / \mathbf{d l}^{6}\right)\end{array}$ & $\begin{array}{l}\text { Marker of endothelial injury/activation coagulation } \\
\text { protein, roll in collagen binding, platelet glycoprotein } \\
\text { Ib binding and factor VIII stabilization. }\end{array}$ \\
\hline & $\begin{array}{l}\text { Plasminogen activator inhibitor-1 } \\
\left(47.1 \mathrm{ng} / \mathrm{ml}^{7}\right)\end{array}$ & $\begin{array}{l}\text { Principal inhibitor of fibrinolysis (Inhibitors of } \\
\text { plasminogen activators and plasmin production), } \\
\text { serine protease inhibitor. }\end{array}$ \\
\hline & $\begin{array}{l}\text { Lipoprotein } \\
\left(11.1-78.1 \mathrm{mg} / \mathrm{dl}^{8}\right)\end{array}$ & Atherosclerogenic and thrombogenic plasma protein. \\
\hline \multirow[t]{4}{*}{$\begin{array}{l}\text { Positive } \quad \text { Minor } \text { APP, } \\
\text { increase } \sim 0.5 \text { folds }\end{array}$} & $\begin{array}{l}\text { Ceruloplasmin } \\
\left(200-400^{2}\right)\end{array}$ & $\mathrm{Cu}^{2+}$ binding, oxidation of $\mathrm{Fe}^{2+}$. \\
\hline & $\begin{array}{l}\text { Complement component } 3 \\
\left(600-1400^{2}\right)\end{array}$ & Opsonization (chemotaxis) \\
\hline & $\begin{array}{l}\text { Complement component } 4 \\
\left(150-650^{1}\right)\end{array}$ & Opsonization \\
\hline & $\begin{array}{l}\text { Ferritin } \\
\left(12-300 \square \mathrm{g} / \mathrm{I}^{\mathrm{T}} \text { higher in men }\right)\end{array}$ & Oxidizes $\mathrm{FE}^{2+}$, stores $\mathrm{Fe}^{3+}$. \\
\hline \multirow[t]{3}{*}{ Negative APP, decreases } & $\begin{array}{l}\text { Transferrin } \\
\left(1,17-2,5 \mathrm{~g} / \mathrm{l}^{2}\right)\end{array}$ & Iron binding. \\
\hline & $\begin{array}{l}\text { Transerythrin } \\
\left(0,2-0,4 \mathrm{~g} / \mathrm{l}^{2}\right)\end{array}$ & Retinol binding protein and thyroxin. \\
\hline & Antithrombin (0.15 g//9) & $\begin{array}{l}\text { Inhibition of coagulation enzymes, which is } \\
\text { potentiated by heparin. }\end{array}$ \\
\hline
\end{tabular}

\section{a. Positive Acute Phase Proteins}

\subsubsection{C- reactive protein $($ CRP)}

The name is derived due to the ability of the CRP to react with C-polysaccharide isolated from pneumococcal cell walls. It is a member of pentraxin family of proteins. They are ligands for leukocyte Fc $\gamma$ receptors. The CRP gene is located on first chromosome. CRP is synthesized by hepatocytes and is classified as an acute phase protein on the basis of its increase in plasma concentration during infection and inflammation and is a golden marker of inflammation. CRP is synthesized by the liver in response to diverse inflammatory stimuli, including heat, trauma, infection, and hypoxia.[9]

Tillett WS, Francis $\mathbf{T}$ studied serological reactions in pneumonia with a non-protein somatic fraction of pneumococcus. CRP was discovered by Tillett and Francis in laboratory during the course of study of patients with Streptococcus pneumonia infection.[10]

Shah $\mathbf{C}$, Kumar $\mathbf{S}$ and Sinha $\mathbf{S}$ did quantitative estimation of acute-phase protein (CRP) in gingival crevicular fluid in chronic periodontitis, before and after non-surgical therapy. At the end of 45 days there was decreased CRP levels of gingival crevicular fluid was observed. These results has shown that the presence of CRP levels were more significant in gingival crevicular fluid and confirmed the underlying inflammatory component of the disease activity in chronic periodontitis.[11] 
Pejcic A et al evaluated the effect of periodontal therapy on CRP and periodontal pathogens in periodontitis patients. They have concluded that in periodontitis patients, the extent of decrease in CRP levels depended on the severity of the disease and on the periodontal pathogens which are present.[12]

Cutando A et al studied the effect of topical application of melatonin on serum levels of CRP, IL-6 and TNF- $\alpha$ in patients with type 1 or type 2 diabetes and periodontal disease. Local melatonin application in patients with diabetes and periodontal disease resulted in a significant decrease in CRP and IL-6 serum levels.[13]

\subsubsection{Serum amyloid - A:}

SAA structurally resembles an apolipoprotein, and is mainly transported in association with lipoprotein particles, particularly high-density lipoprotein (HDL). The SAA concentration of serum/plasma samples ranges from 1-5 $\mu \mathrm{g} / \mathrm{ml}$. Because SAA itself may extract cholesterol from cells, it is thought that SAA plays a role in cholesterol metabolism and atherosclerosis. Some of the effects described for SAA seem to be minimized or abolished by its association with HDL. The very high expression of SAA gives rise to a completely different pathological problem: the continuous high expression of SAA is the prerequisite for the development of secondary amyloidosis, caused by the conformational change of SAA in an insoluble proteolytic peptide, AA, that deposits as insoluble plaque in major organs.[8]

Cengiz MI et al correlated oral environment and secondary amyloidosis in a case report and suggested that secondary amyloidosis can be slowed down if periodontal conditions can be improved.[14]

Cengiz MI et al studied the interaction between periodontal disease and systemic secondary amyloidosis and found out that serum levels of acute-phase reactants in patients with AA amyloidosis were reduced significantly following nonsurgical periodontal therapy.[15]

\subsubsection{Haptoglobin:}

Haptoglobin ( $\mathrm{Hp})$ is an acute phase protein, primarily synthesized in the liver and secreted into the plasma. Hp is also produced in other tissues including lung, skin, spleen, brain, intestine, arterial vessels and kidney, but to a lesser extent. The normal concentration in human plasma ranges from $0.3-3 \mathrm{mg} / \mathrm{ml}$ and increases several fold in the occurrence of local or systemic inflammation. [8]

Ebersole et al focused on systemic acute-phase reactants, CRP and haptoglobin, in adult periodontitis. Haptoglobin levels were shown to be increased in the serum of patients with periodontitis and the levels were correlated with the disease severity.[16]

Giannopoulou et al evaluated effect of photodynamic therapy, diode laser, and deep scaling on cytokine and acute-phase protein levels in gingival crevicular fluid of residual periodontal pockets. Levels of several cytokines and acute-phase proteins (haptoglobin) significantly changed after treatment regardless of treatment modality.[17]

\subsubsection{Alpha 1-antitrypsin}

Alpha1-Antitrypsin (AAT), also referred to as a1-proteinase inhibitor, is the prototypical member of the SERPIN (an acronym for serine proteinase inhibitor) family of protease inhibitors. The normal plasma concentration of AAT ranges from 0.9 to $1.75 \mathrm{~g} / \mathrm{L}$. AAT is present in all tissues and biological fluids including cerebrospinal fluid, saliva, tears. [8]

Kido et al analyzed proteins in human gingival crevicular fluid. Antimicrobial peptides, such as lactoferrin, $\alpha-1$ antitrypsin, lipocalin, S100A7, S100A8, S100A9 and cathelicidin, were observed by mass spectrometry and western blotting. As multiple protein components in gingival crevicular fluid were analysed at the same time, it helped for the diagnosis of periodontal diseases.[18]

\subsubsection{Lipopolysaccharide binding protein (LBP)}

Lipopolysaccharide (LPS)-binding protein (LBP) was first isolated as a $60 \mathrm{kDa}$ glycoprotein from rabbit serum 25 years ago, and recognized as an acute phase protein that could regulate LPS properties biochemically and biologically.[19] The expression profile of LBP and pro- and anti-inflammatory cytokines in periodontal health and disease shows that a strong interplay among them occurs with a negative correlation between LBP and the ratio of interleukin (IL) - 1b/IL-10.[20]

Ren L, Jin LJ, Leung studied role of lipopolysaccharide binding protein (LBP). It has been shown that the expression levels of LBP peptides in periodontally healthy subjects are significantly higher than those in periodontal patients. Notably, this was the first study which indicated that local expression of LBP played a role in periodontal pathogenesis.[21] 


\subsubsection{Fibrinogen}

Fibrinogen gets accumulated at the site of injury and also in the presence of enzymes (which are released from polymorphonuclear leukocytes and platelets) that will lead to formation of fibrin. Fibrin increases the tensile strength of the wound and stimulates fibroblast proliferation and growth. Fibrinogen is synthesized by hepatocytes and is increased by approximately 2- to 4-fold. It can also be stimulated by fibrinogen or fibrin degradation products. This indicates presence of feedback amplification loop for which macrophages are required.[22]

Ebersole et al studied systemic manifestations of periodontitis in the non-human primate. Fibrinogen have been observed in the periodontal disease process. The increase in this molecule is associated with progression of periodontitis.[23]

Ide $\mathbf{M}$ et al studied effect of treatment of chronic periodontitis on levels of serum markers of acutephase inflammatory and vascular responses. Blood was analyzed to determine serum and plasma fibrinogen. Treatment improved plaque and bleeding scores and reduced probing depths. However, there were no statistically significant changes in levels of any of the systemic markers. The levels of vascular markers were not affected by improvement in periodontal health.[24]

\subsubsection{Ceruloplasmin}

Ceruloplasmin is a ferroxidase enzyme that in humans is encoded by the $C P$ gene. Ceruloplasmin is the major copper-carrying protein in the blood and in addition plays a role in iron metabolism. It was first described in 1948. It is an enzyme synthesized in the liver containing 6 atoms of copper in its structure. Ceruloplasmin carries about $70 \%$ of the total copper in human plasma while albumin carries about $15 \%$. The molecular weight of human ceruloplasmin is reported to be $151 \mathrm{kDa}$.[25]

Sweeney SC studied alterations in tissue and serum Ceruloplasmin $(\mathrm{Cp})$ concentration associated with inflammation and stated that the amount of ceruloplasmin in man during periodontal disease was increased approximately 15 times at the injured site in gingival tissues.[26]

Harshavardhana MB et al evaluated serum ceruloplasmin in aggressive and chronic periodontitis patients and concluded serum ceruloplasmin levels increased in both aggressive and chronic periodontitis patients, but more in aggressive periodontitis patients making it a potential marker for diagnosis of periodontitis.[27]

Sezer $\mathbf{U}$ et al studied the effect of chronic periodontitis on oxidative status in patients with rheumatoid arthritis (RA). In this study the ceruloplasmin activity was not significantly associated with chronic periodontitis and rheumatoid arthritis.[28]

\subsubsection{Mannose- binding lectins (MBL)}

Mannose-binding lectin (MBL) is a protein belonging to the family of collectins and is considered to be an important component of the innate immune system. MBL is primarily produced in the liver and circulates in the blood. It primarily recognizes and binds to specific sugar groups that are displayed on the surface of microorganisms.[29] Interestingly, the periodontal pathogens Aggregatibacter actinomycetemcomitans and Porphyromonas gingivalis also appear to have mannose-containing polysaccharides on the cell surface, which can be a potential target for MBL binding.[30]

Gaie et al focused on plasma levels of mannose-binding lectin (MBL) in relation to periodontitis and smoking. The results showed that MBL plasma concentrations were not significantly different in moderate and severe periodontitis compared to controls. Also, the prevalence of MBL deficiency was not found to be different between controls and moderate and severe periodontitis $(45 \%, 37 \%$, and 36\%).[31]

Louropoulou et al studied MBL gene polymorphisms in relation to periodontitis. On the basis of genotyping, three phenotypes with regard to MBL production were distinguished: high-producers, lowproducers and deficient subjects. No differences in the genotype frequencies were observed between test and control.[32]

\subsubsection{Complement components}

The complement system is a group of serum proteins whose general function is to regulate the inflammatory response. Several of the components are acute phase reactants, which increases during infection.[22]

Tomoko et al did comparative analysis of serum proteins in relation to rheumatoid arthritis (RA) and chronic periodontitis (CP). The results suggest that patients with RA and CP may exhibit three serum proteins (complement component 3, complement factor $\mathrm{H}$, and ceruloplasmin) with different levels compared with healthy controls and patients with RA only or CP only.[33] 


\subsubsection{Plasminogen}

The plasminogen-activating system is of prime importance in extracellular proteolysis. It acts in physiological and pathological reactions, neoplastic growth and its invasion. Plasminogen activators are serine proteases.

They are of two types:

1. Tissue/blood vessel type PA (t-PA)

2. Urokinase type PA (u-PA).

The t-PA and u-PA form part of the complex enzyme cascade which is involved in fibrinolysis for conversion of proenzyme plasminogen into the broad-spectrum proteinase and plasmin. In periodontitis plasmin is formed at sites of inflammation, activates the proMMPs into proteases which are specific for elastin and collagen, also responsible for the degradation of fibrin and extracellular matrix (ECM). [34]

Festa et al studied elevated levels of acute-phase proteins and plasminogen activator inhibitor-1 (PAI1) predicted the development of Type- 2 diabetes and found that chronic inflammation precedes the development of Type-2 diabetes. High PAI-1 levels in subjects with normal glucose tolerance (NGT) may help to identify a high-risk population with the potential to prevent both atherosclerotic disease and Type-2 diabetes.[35]

\subsubsection{Pentraxin-3}

Pentraxin-3(PTX3) is an APP, synthesis is stimulated in macrophages, endothelial cells, myeloid cells, and dendritic cells by cytokines and endotoxins such as bacterial products, interleukin-1, and TNF. It is expressed in response to a variety of inflammatory or infectious stimuli and interacts with different ligands. Interaction of PTX3 with surface immobilized Complement C1q results in activation of classical complement cascade. It is a true independent indicator of disease activity.[36]

Pradeep AR et al compared the levels of Pentraxin-3 in GCF and Plasma in Periodontal Health and Disease. The Pentraxin-3 levels in GCF and plasma were increased in subjects with periodontitis. Hence, it can be considered as an inflammatory marker in periodontal disease.[37]

Pinar G et al evaluated saliva and serum levels of PTX3 in patients with generalized chronic and aggressive periodontitis and defined PTX3 as diagnostic tools for periodontal inflammation.[38]

\subsubsection{Chitinase}

Chitinases are glycosyl hydrolases with the sizes ranging from $20 \mathrm{kDa}$ to about $90 \mathrm{kDa}$. They are present in a wide range of organisms such as bacteria, fungi, yeasts, plants, actinomycetes, arthropods, and humans. Mammalian chitinases belong to the family 18 of glycosyl hydrolases (GH18), which can be divided into chitinase like proteins with no enzymatic activity, and enzymatically active true chitinases. Chitotriosidase was the first mammalian chitinase to be identified.[39]

Steijn $\mathbf{V}$ et al evaluated chitinase in whole saliva and glandular human saliva and in whole saliva of patients with periodontal inflammation. Serum albumin levels were also measured. The absence of correlation between chitinase activity levels in plasma and saliva of periodontitis patients indicated that the (increased) chitinase activity did not originate from blood leaked into the oral cavity.[40]

Steijn $\mathbf{V}$ et al evaluated the effect of periodontal treatment on the activity of chitinase in whole saliva of periodontitis patients. After the treatment of the disease there was no decrease in chitinase concentration. The clinical parameters such as bleeding on probing, plaque index, probing pocket depth and clinical attachment loss were decreased. [41]

\subsubsection{YKL-40}

YKL-40 is a chitinase-like protein and is secreted from cells in the airway mucosa, for example, neutrophils, macrophages, and airway epithelial cells. YKL-40 regulates vascular endothelial growth factor and has a role in inflammation, cell proliferation and differentiation, remodeling of the extracellular matrix, and protection against apoptosis.[42]

Mygind ND et al evaluated the influence of statin treatment on the inflammatory biomarkers YKL-40 and highly sensitive CRP (hs-CRP) in patients with stable coronary artery disease and concluded that hs-CRP, but not YKL-40, is associated with the cholesterol levels in statin treated patients. This indicates that YKL-40 could be a superior prognostic biomarker in patients with stable CAD, since it is independent of changes in cholesterol levels in both statin and non-statin treated patients.[43]

Keles Z et al did analysis of YKL-40 acute-phase protein and interleukin-6 levels in periodontal disease. YKL-40 levels in GCF as well as serum YKL-40 and IL-6 levels increased from gingivitis to periodontitis. This study stated that the YKL-40 molecule might be a potential novel inflammatory marker of periodontal disease.[44] 


\subsubsection{Ferritin}

Ferritin is a positive acute phase reactant, exhibiting increased levels in blood during the acute phase response. Nevertheless, the precise role of ferritin as an acute phase reactant remains to be clarified. As for other acute phase proteins, ferritin is produced and secreted by hepatocytes. However, ferritin is also produced and secreted by other cell types, including macrophages and cancer cells. [8]

Chakraborty and Ko Y studied the effect of non-surgical periodontal therapy on serum ferritin levels. He found Patients with CP showed higher concentrations of serum ferritin than periodontally healthy controls. Significant reductions in serum ferritin levels were observed at the 3-month assessment after periodontal treatment, and the post-treatment serum ferritin values were comparable to those of controls. [45]

Fang et al studied the clinical response and systemic parameters (interleukin-6, ferritin, albumin, creatinine, blood urea nitrogen, and transferrin) of non-surgical periodontal therapy in end-stage renal disease (ESRD) patients. The clinical periodontal parameters showed significant improvement in the intervention group.[46]

\subsection{Negative Acute Phase Proteins \\ 7.2.1 Albumin and transferrin}

Albumin and transferrin, the serum iron transport protein, are decreased during inflammation, potentially to starve the microorganisms of iron required for growth and virulence expression. It appears that cytokines, including IL-1, IL-6 and tumor necrosis factor a, are important down regulators of the synthesis of these acute-phase reactants.[22]

Rodrigues et al studied periodontal status and serum biomarkers levels in haemodialysis patients. They have found that the periodontitis group had albumin and phosphorus serum levels lower than the no periodontitis group. Thus, there was a positive association of periodontitis with hypoalbuminaemia and a negative association with hyperphosphataemia. These findings suggest that periodontitis is associated with albumin and phosphorus serum levels in haemodialysis patients.[47]

\section{Conclusion}

Inflammation is a complex, highly orchestrated process involving many cell types and molecules, some of which initiate, amplify, or sustain the process, some of which attenuate it, and some of which aid resolution. A number of the participating AAPs are multifunctional and contribute to both the enhancement and the inhibition of inflammation at different points in its evolution. The outcome of the acute inflammatory response is most likely to be determined by the orchestrated generation of a specific profile of APPs, their concentrations and molecular forms in the microenvironment. Diseases associated with chronic inflammation may be due to an inadequate acute-phase response driven by APPs, their concentration and molecular form and/or an inability to eliminate invading pathogens and to rapidly to resolve the inflammatory processes. Often, a single APP is regarded as a marker for inflammation to aid in diagnosis and assesses response to treatment, however we believe one needs to see the profile of several APPs in action to understand function in relation to disease which may help in turn to determine prognosis.

\section{References}

[1]. Saini R, Saini S, Sharma S. Periodontitis: A risk factor to respiratory diseases. Lung India. 2010;27(3):189.

[2]. Smitha CN, Soni S, Basu SK. Role of C-Reactive protein and periodontal disease in systemic health: A review. Journal of Advanced Dental Research. 2011:2(1):1-6.

[3]. Ceciliani F, Giordano A, Spagnolo V. The systemic reaction during inflammation: the acute-phase proteins. Protein Pept Lett. 2002;9(3):211-23

[4]. Gabay C, Kushner I. Acute-phase proteins and other systemic responses to inflammation. N Engl J Med. 1999;11:340(6):448-54

[5]. Zhou YF, Csako G, Grayston JT, Wang SP, Yu ZX, Shou M, Leon M, Epstein SE. Lack of association of restenosis following coronary angioplasty with elevated C-reactive protein levels or seropositivity to Chlamydia pneumoniae. Am J Cardiol. 1999;84(5):595-8.

[6]. Koj A. Initiation of acute phase response and synthesis of cytokines. Biochim Biophys Acta. 1996;1317(2):84-94.

[7]. Tirziu E. Acute-phase proteins in immune response . Lucrari Stiinłifice Medicina Veterinara.2009;XLII (1):329-339.

[8]. Francisco Veas, Acute phase proteins: Regulation and functions of acute phase proteins, 1 (Croatia: InTech, 2011)25-60.

[9]. Zambson JJ, Reynolds JS, Chen P, Genco RJ, Slots J, Thomas ER. Microbiology of Periodontal Disease. In: Slots J, Taubman JE, editors. USA: St. Louis; $1985: 32-40$.

[10]. Tillett WS, Francis T. Serological reactions in pneumonia with a non-protein somatic fraction of pneumococcus. J Exp Med. 1930;52(4):561-71.

[11]. Shah C, Kumar S, Sinha S. Quantitative estimation of acute-phase protein in gingival crevicular fluid in chronic periodontitis, before and after non-surgical therapy- A clinico biochemical study. J Int Oral Health 2010;2(4):23-31.

[12]. Pejcic A, Kesic L, Milasin J. Association between Periodontopathogens and CRP Levels in Patients with Periodontitis in Serbia. J Dent Res Dent Clin Dent Prospects. 2011;5(1):10-6

[13]. Cutando A, Montero J, Gómez-de Diego R, Ferrera MJ, Lopez-Valverde A. Effect of topical application of melatonin on serum levels of C-reactive protein (CRP), interleukin-6 (IL-6) and tumor necrosis factor-alpha (TNF- $\alpha$ ) in patients with type 1 or type 2 diabetes and periodontal disease. J Clin Exp Dent. 2015;7(5):628-33.

[14]. Cengiz MI, Wang HL, Yıldız L. Oral involvement in a case of AA amyloidosis: a case report. J Med Case Reports. 2010; 4:200-6. 
[15]. Cengiz MI, Yayla N, Cengiz K, Taskın E. Interaction between periodontal disease and systemic secondary amyloidosis: from inflammation to amyloidosis. J. Periodontol. 2011; 82:566-74.

[16]. Ebersole JL, Machen RL, Steffen MJ, Willmann DE. Systemic acute-phase reactants, C-reactive protein and haptoglobin, in adult periodontitis. Clin Exp Immunol. 1997;107(2):347-52.

[17]. Giannopoulou C, Cappuyns I, Cancela J, Cionca N, Mombelli A. Effect of photodynamic therapy, diode laser, and deep scaling on cytokine and acute-phase protein levels in gingival crevicular fluid of residual periodontal pockets. J Periodontol. 2012;83(8):101827.

[18]. Kido J, Bando M, Hiroshima Y, Iwasaka H, Yamada K, Ohgami N, Nambu T, Kataoka M, Yamamoto T, Shinohara Y, Sagawa I, Nagata T. Analysis of proteins in human gingival crevicular fluid by mass spectrometry. J Periodontal Res. 2012 Aug;47(4):488-99.

[19]. Tobias PS, Soldau K, Ulevitch RJ. Isolation of a lipopolysaccharide-binding acute phase reactant from rabbit serum. J Exp Med 1986;164:777-793.

[20]. Ren L, Jiang ZQ, Fu Y, Leung WK, Jin LJ. The interplay of lipopolysaccharide-binding protein and cytokines in periodontal health and disease. J Clin Periodontol 2009;36:619-626.

[21]. Ren L, Jin L, Leung WK. Local expression of lipopolysaccharide-binding protein in human gingival tissues. J Periodontal Res. 2004;39(4):242-8.

[22]. Ebersole JL, Cappelli D. Acute-phase reactants in infections and inflammatory diseases. Periodontol 2000. 2000;23:19-49.

[23]. Ebersole JL, Cappelli D, Mott G, Kesavalu L, Holt SC, Singer RE. Systemic manifestations of periodontitis in the non-human primate. J Periodontal Res. 1999;34(7):358-62.

[24]. Ide M, McPartlin D, Coward PY, Crook M, Lumb P, Wilson RF. Effect of treatment of chronic periodontitis on levels of serum markers of acute-phase inflammatory and vascular responses. J Clin Periodontol. 2003;30(4):334-40.

[25]. Gaware V, Kotade K, Dhamak K, Somawanshi S. Ceruloplasmin its role and significance: a review. IJBR. 2010;1 (4):153-162.

[26]. Sweeney SC. Alterations in tissue and serum ceruloplasmin concentration associated with inflammation. J Dent Res. 1967;46(6):1171-6.

[27]. Harshavardhana B, Rath SK, Mukherjee M. Evaluation of serum ceruloplasmin in aggressive and chronic periodontitis patients. J Indian Soc Periodontol. 2013;17(3):333-7.

[28]. Sezer U, Erciyas K, Ustün K et al. Effect of chronic periodontitis on oxidative status in patients with rheumatoid arthritis. J Periodontol. 2013;84(6):785-92.

[29]. Turner M. W. Mannose-binding lectin: the pluripotent molecule of the innate immune system. Immunology Today. 1996;17: 532540 .

[30]. Bramanti T. E, Wong G. G, Weintraub S. T, Holt S. C. Chemical characterization and biologic properties of lipopolysaccharide from Bacteroides gingivalis strains W50, W83, and ATCC 33277. Oral Microbiology and Immunology. 1989; 4: 183-192.

[31]. Maffei G, Brouwer N, Dolman KM, van der Velden U, Roos D, Loos BG. Plasma levels of mannan-binding lectin in relation to periodontitis and smoking. J Periodontol. 2005;76(11):1881-9.

[32]. Louropoulou A, van der Velden U, Schoenmaker T, Catsburg A, Savelkoul PH, Loos BG. Mannose-binding lectin gene polymorphisms in relation to periodontitis. J Clin Periodontol. 2008;35(11):923-30.

[33]. Yokoyama T, Kobayashi T, Ito $\mathrm{S}$ et al. Comparative analysis of serum proteins in relation to rheumatoid arthritis and chronic periodontitis. J Periodontol. 2014;85(1):103-12.

[34]. Buduneli N, Buduneli E, Kardesler L, Lappin D, Kinane DF. Plasminogen activator system in smokers and non-smokers with and without Periodontal diseases. J Clin Periodontol. 2005;32(4):417-24.

[35]. Festa A, D'Agostino R Jr, Tracy RP, Haffner SM; Insulin Resistance Atherosclerosis Study. Elevated levels of acute-phase proteins and plasminogen activator inhibitor-1 predict the development of type 2 diabetes: the insulin resistance atherosclerosis study. Diabetes. 2002;51(4):1131-7.

[36]. Mantovani A, Garlanda C, Doni A, Bottazzi B. Pentraxins in innate immunity: From C-reactive protein to the long pentraxin PTX3. J Clin Immunol. 2008;28(1):1-13.

[37]. Pradeep A, Rahul K, Raghavendra N, Sharma A. Levels of pentraxin-3 in gingival crevicular fluid and plasma in periodontal health and disease. J Periodontol. 2011;82(5):734-41.

[38]. Pinar G, Nizam N, Nalbantsoy A, Buduneli N. Saliva and serum levels of pentraxin-3 and interleukin-1 $\beta$ in generalized aggressive and chronic periodontitis. J Periodontol. 2014;85(3):40-46.

[39]. Hamid R, Khan MA, Ahmad M et al. Chitinases: An update. J Pharm Bioallied Sci. 2013;5(1): 21-29.

[40]. Van Steijn GJ, Amerongen AV, Veerman EC, Kasanmoentalib S, Overdijk B. Chitinase in whole and glandular human salivas and in whole saliva of patients with periodontal inflammation. Eur J Oral Sci. 1999;107(5):328-37.

[41]. Van Steijn GJ, Amerongen AV, Veerman EC, Kasanmoentalib S, Overdijk B. Effect of periodontal treatment on the activity of chitinase in whole saliva of periodontitis patients. J Periodontal Res. 2002;37(4):245-9.

[42]. Hansen JW, Thomsen SF, Porsbjerg C, YKL-40 and genetic status of CHI3L1 in a large group of asthmatics. European clinica respiratory Journal. 2015; 2:1-8.

[43]. Mygind ND, Harutyunyan MJ, Mathiasen AB et al. The influence of statin treatment on the inflammatory biomarkers YKL-40 and HsCRP in patients with stable coronary artery disease. Inflamm Res. 2011;60(3):281-7.

[44]. Keles ZP, Keles GC, Avci B, Cetinkaya BO, Emingil G. Analysis of YKL-40 acute-phase protein and interleukin-6 levels in periodontal disease. J Periodontol. 2014;85(9):1240-6.

[45]. Ko Y, Park JB, Park YG. Re: Effect of non-surgical periodontal therapy on serum ferritin levels: an interventional study. Chakraborty S, Tewari S, Sharma RK, Narula SC. (J Periodontol 2014;85:688 to 696.). J Periodontol. 2015;86(2):175.

[46]. Ardila CM, Guzmán IC. Comparison of serum amyloid A protein and C-reactive protein levels as inflammatory markers in periodontitis. J Periodontal Implant Sci. 2015;45(1):14-22.

[47]. Rodrigues VP, Libério SA, Lopes FF, et al. Periodontal status and serum biomarkers levels in haemodialysis patients. J Clin Periodontol. 2014;41(9):862-8. 